\title{
IMPLEMENTASI SISTEM INFORMASI PENDAFTARAN YUDISIUM PADA STMIK STIKOM INDONESIA
}

\author{
I Putu Gede Budayasa ${ }^{1}$, I Putu Adi Pratama ${ }^{2}$, I Made Surendra ${ }^{3}$ \\ ${ }^{1,2,3}$ Teknik Informatika, STMIK STIKOM Indonesia \\ Jalan Tukad Pakerisan No.97 Panjer, Denpasar \\ E-mail: budayasa@stiki-indonesia.ac.id ${ }^{1}$, putudipa@gmail.com ${ }^{2}$, zuren.dra96@gmail.com $^{3}$
}

\begin{abstract}
ABSTRAK
STMIK STIKOM Indonesia merupakan institusi pendidikan yang secara rutin menyelenggarakan yudisium. Pada prosesnya, yudisium yang diselenggarakan setiap 3 (tiga) bulan sekali, STMIK STIKOM Indonesia telah memiliki dan menjalankan mekanisme yang melibatkan sistem informasi berbasis komputer. Sistem ini digunakan sebagai media pendaftaran bagi mahasiswa yang akan mengikuti yudisium. Mekanisme yang berjalan dimulai dari proses pendaftaran melalui sistem informasi kemudian dilanjutkan dengan verifikasi dan validasi oleh beberapa pejabat struktural selaku pemangku kepentingan. Selama 15 (lima belas) kali pelaksanaan hingga bulan Maret 2018, mekanisme yudisium tersebut memiliki beberapa kelemahan. Meski pendaftaran dilakukan melalui sistem informasi, proses verifikasi dan validasi oleh pejabat struktural dilakukan secara paper based. Ini menimbulkan permasalahan dari segi efisiensi, pengarsipan dokumen pengajuan seluruh mahasiswa, serta kesulitan yang ditemui mahasiswa ketika pejabat struktural tidak berada di tempat. Diperlukan mekanisme pendaftaran, verifikasi dan validasi data yudisium yang lebih baik, serta sebuah sistem yang memungkinkan proses tersebut seluruhnya dilakukan secara terkomputerisasi.
\end{abstract}

Kata Kunci: pendaftaran, yudisium, sistem informasi.

\section{ABSTRACT}

STMIK STIKOM Indonesia is an educational institution that routinely organizes judiciaries. In the process, the judiciary is held every 3 (three) months, STMIK STIKOM Indonesia has and runs a mechanism that involves a computer-based information system. This system is used as a media for registration for students who will join the Judiciary. The mechanism that starts from the registration process through the information system is then followed by verification and validation by several structural officials as stakeholders. For 15 (fifteen) times of implementation until March 2018, the judiciary mechanism has several weaknesses. Although registration is done through an information system, the verification and validation process by structural officials is carried out in a paper-based manner. This raises problems in terms of efficiency, filing documents for all student submissions, and the difficulties students encounter when structural officials are not in place. Better mechanisms for registration, verification and validation of judiciary data are needed, as well as a system that allows the entire process to be done in a computerized manner.

Keywords: registration, judiciary, information system.

\section{PENDAHULUAN}

\subsection{Latar Belakang}

Proses pendaftaran yudisium saat ini dimulai dari mahasiswa melakukan pengisian data secara daring pada sistem informasi yang disebut SIMPOSIUM. Setelah mengisi data secara lengkap mahasiswa selanjutnya mencetak form tersebut untuk divalidasi oleh pejabat yudisium pada divisi akademik, perpustakaan, laboratorium, penyelenggara sertifikasi, program studi, kemahasiswaan dan bagian keuangan. Validasi dilakukan oleh masingmasing pejabat dengan menandatangani dan memberikan stempel pada kolom yang telah disediakan dalam form pendaftaran mahasiswa. Sebelum melakukan validasi, masing-masing pejabat divisi sebelumnya akan memverifikasi data mahasiswa untuk menilai layak atau tidaknya mahasiswa bersangkutan mendapat validasi.
Meski pendaftaran dilakukan melalui sistem informasi, proses verifikasi dan validasi oleh pejabat struktural dilakukan secara paper based. Selain itu di setiap periode pendaftaran yudisium selalu terdapat mahasiswa yang terlambat melakukan verifikasi dan validasi. Untuk itu perlu dilakukan analisis terhadap mekanisme yang dijalankan sehingga dapat diidentifikasi berbagai kendala dan permasalahan yang dihadapi. Hasil dari analisis selanjutnya dapat digunakan untuk menyusun mekanisme baru yang lebih baik bagi pihak institusi dalam memberikan pelayanan kepada mahasiswa khususnya pada proses pendaftaran, verifikasi dan validasi data yudisium. Mekanisme yang dihasilkan selanjutnya akan digunakan untuk membangun sistem informasi untuk menjalankan mekanisme tersebut. Sistem informasi dibangun berbasis website sehingga memberikan kemudahan akses bagi pengguna. 


\subsection{Rumusan Masalah}

Permasalahan yang akan dibahas pada penelitian ini berdasarkan latar belakang yang disampaikan adalah bagaimana implementasi sistem informasi pendaftaran yudisium pada STMIK STIKOM Indonesia.

\subsection{Batasan Masalah}

Batasan dari permasalahan yang dibahas pada penelitian ini meliputi:

a. Hanya membahas proses pendaftaran yudisium oleh mahasiswa, verifikasi dan validasi data pendaftaran oleh pejabat struktural.

b. Sistem informasi dimemodelkan dengan pendekatan berorientasi obyek, serta dibangun berbasis website.

\subsection{Manfaat Penelitian}

Hasil dari penelitian ini dapat memberikan manfaat sebagai berikut :

a. Membantu mahasiswa dalam memantau status pengajuan yudisium di masing-masing divisi.

b. Mengurangi penggunaan berkas fisik sehingga memudahkan pihak program studi dalam melakukan pengarsipan dan menghindari terjadinya kecurangan berupa pemalsuan berkas.

c. Memudahkan divisi-divisi yang terlibat dalam pendaftaran yudisium saat memberi validasi terhadap pengajuan mahasiswa karena sistem informasi terlebih dahulu memastikan syarat untuk divalidasi telah terpenuhi

\section{PEMBAHASAN}

Penelitian terbagi ke dalam beberapa langkah yang dimulai dari pengamatan terhadap proses yang berjalan di masing-masing divisi, penelitian akan memfokuskan pada kendala-kendala yang dihadapi. Dokumen yang digunakan juga akan ditelaah sehingga analisis terhadap proses bisnis dapat dilakukan secara komprehensif. Hasil analisis selanjutnya akan digunakan sebagai dasar untuk merancang ulang proses bisnis dengan mempertimbangkan bahwa kendala-kendala yang dihadapi dapat diselesaikan. Hasil rancangan selanjutnya digunakan untuk memodelkan dan membangun sistem informasi. Penelitian diakhiri dengan melakukan pengujian terhadap sistem yang dibangun.

\subsection{Analisis Kebutuhan}

Kebutuhan terhadap proses bisnis yang lebih efisien dapat dirumuskan setelah mengkaji beberapa kelemahan pada proses bisnis sebelumnya. Kelemahan pada proses bisnis sebelumnya adalah penggunaan berkas fisik sehingga memunculkan beberapa kendala seperti antrean mahasiswa di ruangan setiap divisi, serta pemeriksaan ulang seluruh berkas oleh staf program studi. Pemeriksaan yang terakhir disebutkan ditujukan untuk menghindari kemungkinan kecurangan oleh mahasiswa.

Efisiensi pada kondisi inilah yang dapat diusulkan pada proses bisnis yang baru, dimana proses pemeriksaan tidak perlu dilakukan lagi oleh staf program studi mengingat pada divisi-divisi yang terlibat telah melakukan pemeriksaan sebelumnya. Untuk mencapai efisiensi tersebut maka berkas fisik yang digunakan sebelumnya perlu diganti dengan pengelolaan data secara digital. Selain memangkas proses pemeriksaan ulang, pengelolaan data secara digital juga meningkatkan efisiensi ruang penyimpanan data.

\subsection{Pemodelan Sistem}

Sistem informasi menggunakan pemodelan beroientasi obyek menggunakan UML, aktor yang terlibat dalam penggunaan sistem informasi yudisium ditunjukkan pada Gambar 1 berjumlah lima aktor yaitu Mahasiswa, Admin UPS, WK III, Pejabat Yudisium, dan Admin Prodi. Use case diagram yang dirancang memiliki 11 (sebelas) buah use case, dimana terdapat use case yang dijalankan oleh beberapa aktor. Login adalah salah satu use case yang dijalankan oleh semua aktor. Ini menunjukkan bahwa hanya pengguna yang sudah terdaftar saja yang dapat mengakses sistem informasi. Pengelolaan terhadap pengguna sistem dilakukan oleh admin program studi, selain juga melakukan pengelolaan periode pendaftaran.

Bagian terpenting adalah melakukan pendaftaran dan validasi data, yang dijalankan oleh mahasiswa dan pejabat yudisium.

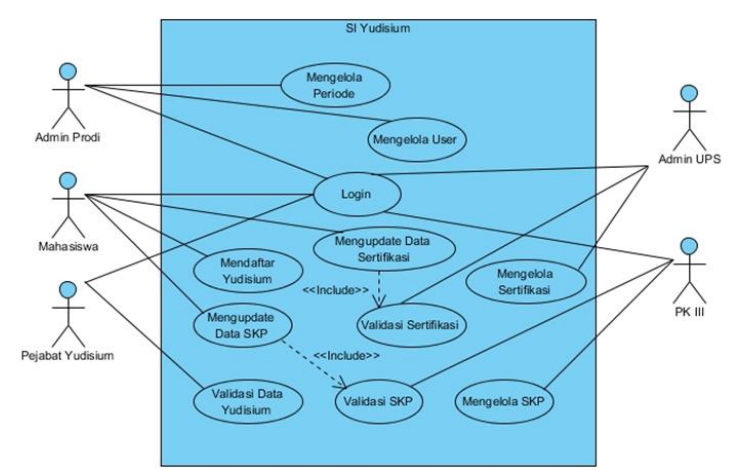

Gambar 1. Use Case Diagram

Sesuai dengan proses bisnis yang telah dirancang, yang dimaksud dengan Pejabat Yudisium terdiri dari Wakil Ketua I, Kepala UPT Perpustakaan, Kepala Lembaga Pengembangan Inovasi dan Kreatifitas, dan Wakil Ketua II. Use case yang dijalankan juga telah disesuaikan dengan proses bisnis yang berjumlah sebelas use case.

\subsection{Implementasi Sistem}

Sistem informasi pendaftaran yudisium dibangun berbasis website yang melibatkan 10 (sepuluh) peran pengguna mulai dari mahasiswa, pejabat yudisium, hingga admin program studi. 
Mahasiswa yang telah memiliki akun dan berhasil login akan diarahkan ke halaman dashboard. Halaman dashboard mahasiswa menunjukkan status pengajuan di masing-masing divisi, seperti ditunjukkan pada Gambar 2. Selain status pengajuan, halaman ini juga berisi tata cara pengisian data.

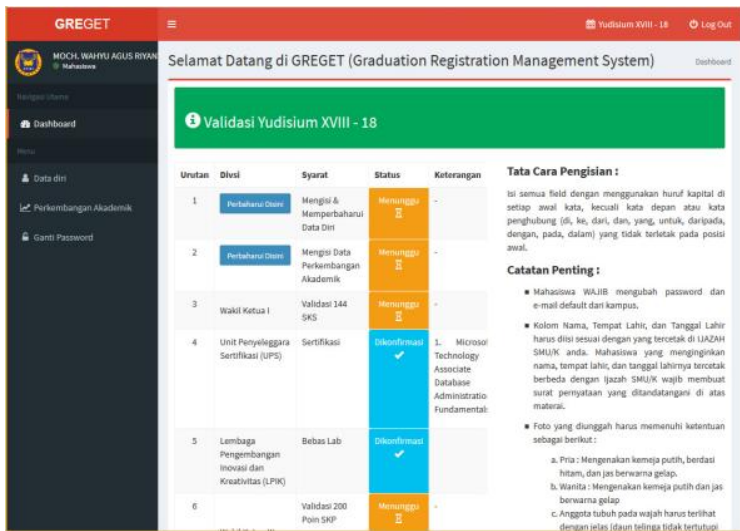

Gambar 2. Halaman Dashboard Mahasiswa

Hal pertama yang wajib dilakukan mahasiswa adalah melengkapi data diri seperti pada Gambar 3 dan perkembangan akademik. Setelah melengkapi data diri dan perkembangan akademik, selanjutnya pengajuan mahasiswa dapat divalidasi oleh divisi yang bertanggung jawab, mulai dari persyaratan akademik hingga pembayaran administrasi yudisium. Status validasi dari masing-masing divisi juga dapat dipantau oleh mahasiswa melalui halaman dashboard.

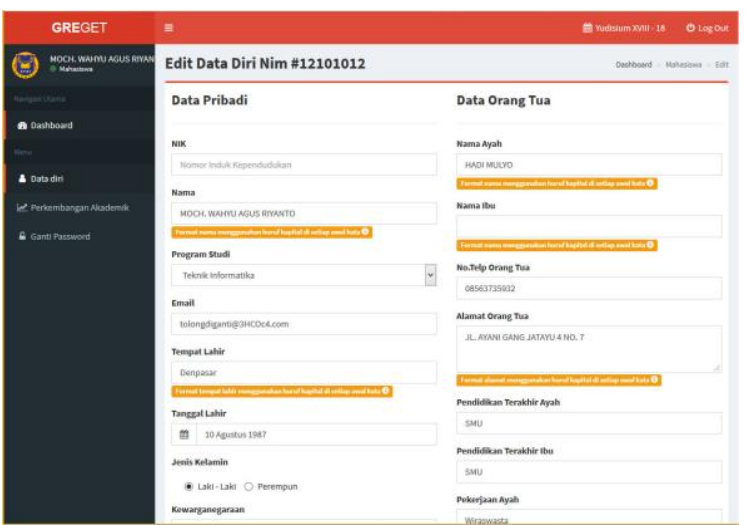

\section{Gambar 3. Isian Data Diri Mahasiswa}

Validasi persyaratan akademik dilakukan oleh wakil ketua bidang akademik ditujukan untuk memastikan persyaratan akademik mahasiswa terpenuhi. Syarat yang meliputi jumlah SKS mata kuliah wajib dan pilihan dengan total 144 SKS. Halaman yang ditunjukkan Gambar 4 adalah daftar mahasiswa yang telah mengisi data diri dan perkembangan akademik, serta sertifikasi yang dimiliki oleh mahasiswa bersangkutan.

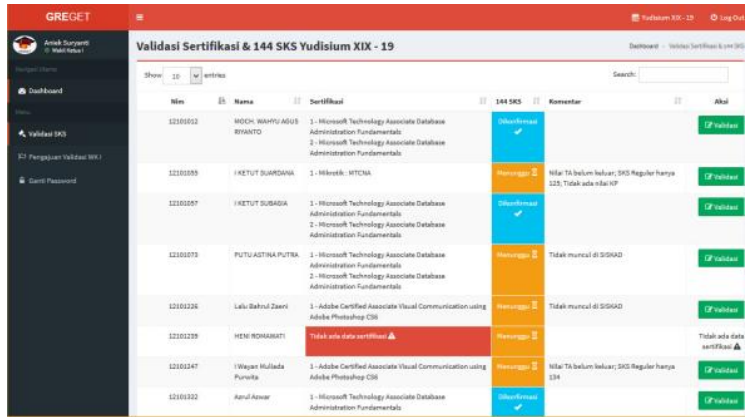

Gambar 4. Halaman Validasi Pejabat Yudisium

Data pengajuan seluruh mahasiswa akan tampil pada halaman admin program studi. Halaman ini menunjukkan beberapa informasi yang dapat membantu admin dalam memamtau perkembangan status pendaftaran mahasiswa. Jumlah mahasiswa yang telah didaftarkan pada periode berjalan, jumlah pengajuan yang sudah valid, dan jumlah pengajuan menunggu valid ditampilkan di bagian atas halaman. Sedangkan perkembangan pengajuan mahasiswa ditampilkan dalam grafik batang. Grafik tersebut menunjukkan jumlah mahasiswa yang belum tervalidasi pada masing-masing persyaratan pendaftaran yudisium. Halaman dashboard admin ditunjukkan pada Gambar 5.

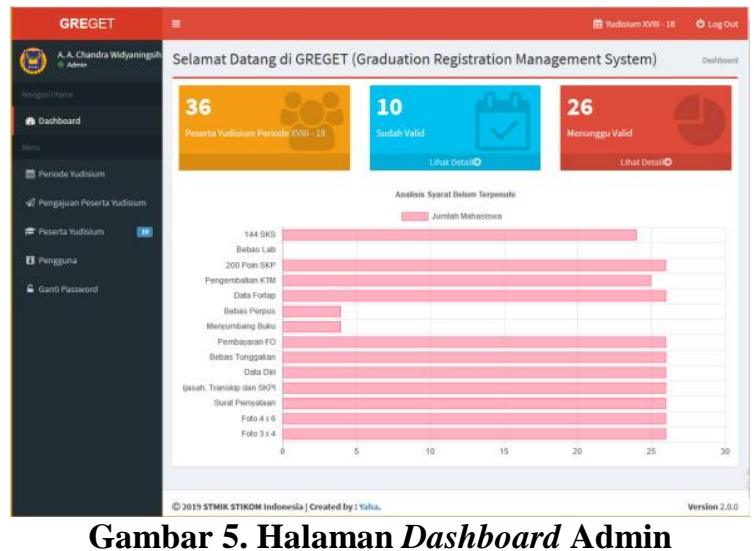

Mahasiswa yang telah memenuhi semua persyaratan akan ditampilkan pada halaman peserta yudisium. Gambar 6 menunjukkan terdapat 10 orang mahasiswa telah memenuhi seluruh persyaratan namun terdapat satu orang mahasiswa yang belum divalidasi oleh admin prodi. Status validasi ditunjukkan dengan perbedaan warna pada kolom Acc Prodi. Selanjutnya admin prodi dapat memvalidasi pengajuan tersebut dengan memastikan data isian telah valid. Validasi isian data dilakukan dengan menggunakan fitur validasi pada kolom aksi. Menekan tombol validasi akan memunculkan sebuah jendela baru yang berisi checklist kelengkapan data, seperti ditunjukkan pada Gambar 7. 


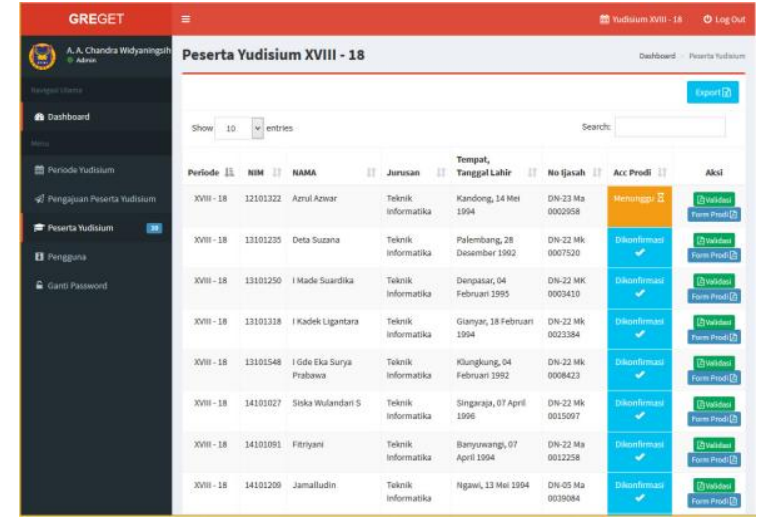

Gambar 6. Halaman Peserta Yudisium

Admin program studi akan menyesuaikan isian data dan beberapa berkas pendukung telah lengkap sebelum memberi centang checklist dan menekan tombol simpan validasi.

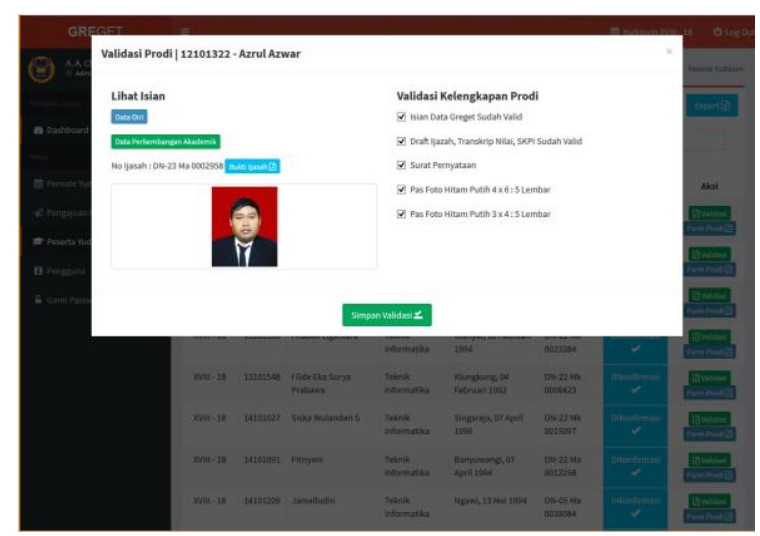

Gambar 7. Jendela Validasi

\subsection{Pengujian Sistem}

Sistem yang telah berhasil dibangun selanjutnya diuji dengan menggunakan User Acceptance Test (UAT) yang melibatkan elemen pengguna sistem. Pengguna sistem yang dilibatkan disesuaikan dengan perannya. Masing-masing peran pengguna diujicoba untuk mengetahui kesesuaian fungsi sistem yang telah diimplementasikan dengan rancangan. Pengujian dilakukan ke 10 (sepuluh) peran pengguna dengan total 28 (dua puluh delapan) kelas uji. Hasil yang diperoleh adalah sebanyak 27 (dua puluh tujuh) kelas uji menghasilkan luaran sesuai dengan rancangan, sedangkan terdapat satu kelas uji yang gagal. Kegagalan terjadi pada proses penambahan data sertifikasi melalui fitur import data dari file Microsoft Excel. Data yang terdapat pada file Microsoft Excel tidak tampil pada daftar sertifikasi. Perbaikan telah dilakukan dan proses penambahan data sertifikasi telah berhasil dijalankan.

\section{KESIMPULAN}

Implementasi sistem informasi pendaftaran yudisium dilakukan dengan membangun sistem berbasis website untuk seluruh pengguna, yang meliputi Mahasiswa, Wakil Ketua I, Unit Penyelenggara Sertifikasi, Lembaga Pengembangan Inovasi dan Kreativitas, Wakil Ketua III, UPT Pengolahan Data Digital, UPT Perpustakaan, Front Office, Akuntan, serta Admin Program Studi. Sistem yang telah dibangun kemudian dijalankan untuk menunjang proses pendaftaran yudisium dengan melibatkan semua pengguna. Pengujian sistem menggunakan User Acceptance Test (UAT) yang dilakukan ke 10 (sepuluh) peran pengguna dengan total 28 (dua puluh delapan) kelas uji.

\section{PUSTAKA}

Booch, G., James, R. \& Ivar, J., 2005. The Unified Modeling Language User Guide Second Edition. United State: Addison Wesley Professional.

Connolly, T. \& Begg, C., 2010. Database Systems A Practical Approach to Design, Implementation, and Management Fifth Edition. Boston: Pearson Education.

Fowler, M., 2005. UML Distilled 3th Ed : Panduan Singkat Bahasa Pemodelan Objek Standar. Yogyakarta: Andi.

Gunawan, D., Dewayani, E., \& Wasino. 2018. Sistem Informasi Distribusi Kerupuk Pabrik AB di Kabupaten Bangka. Jurnal Ilmu Komputer dan Sistem Informasi (JIKSI) Vol.6 No.2, 52-58.

Jogiyanto, H., 2005. Analisis dan Desain Sistem Informasi. Yogyakarta: Andi.

Kadir, A., 2009. Dasar Perancangan dan Implementasi Database Relational. Yogyakarta: Andi.

Kristanto, A., 2008. Perancangan Sistem Informasi dan Aplikasinya. Yogyakarta: Gava Media.

Mahaseptiviana, A., Tjandrarini, A. B., \& Sudarmaningtyas, P. 2014. Analisis dan Perancangan Sistem Informasi Penjualan Air Minum pada CV. Air Putih. Jurnal Sistem Informasi (JSIKA) Vol. 3 No.2.

Mardi, 2001. Sistem Informasi Akuntansi. Bogor: Ghalia Indonesia.

Sutanta, E., 2011. Basis Data dalam Tinjauan Konseptual. Yogyakarta: Andi.

Tantra, R., 2012. Manajemen Proyek Sistem Informasi. Yogyakarta: Andi. 